\title{
The Influence of School Style of Leadership and Working Condition the Productivity of High School Teachers in Muaradua
}

\author{
Mutiah $^{1 *}$, Yasir Arafat ${ }^{1}$ Yenny Puspita ${ }^{1}$ \\ ${ }^{1}$ Universitas PGRI Palembang \\ *Corresponding author. Email: mutiah2016123@gmail.com
}

\begin{abstract}
The aim of this study is to test the influence of the style of leadership on the performance of high school teachers, to measure the influence of the work environment on the performance of high school teachers and to analyze the impact of the main style of leadership and work environment on the performance of high school teachers in the Muaradua district. This research is based on numerical techniques. Research methodology by means of a survey and documentation. Method of data analysis, two-variable product moment correlation analysis and classical assumption testing. The outcomes of this survey have a direct influence on the headmaster's style of leadership on the quality of teachers, a significantly positive impact on the performance of teachers in the work environment, and a positive and significant impact on the headmaster's leadership style and work environment on the quality of high school teachers in the Muaradua district South OKU-Regency.
\end{abstract}

Keywords: Principal Leadership Style, Work Environment and Teacher

\section{INTRODUCTION}

Teacher quality is a very important and urgent factor in education, because teachers play a role as the spearhead of education. The low performance of teachers which results in low processes which in turn will have an impact on the low quality of student output and the low quality of schools. The low quality of schools can affect the level of public trust in schools which in turn has an impact on decreasing the number and quality of student input.

Teachers are the main element throughout the education world, and also more attention was paid to the creation of quality teachers so that this can support the performance of teachers. Teachers also have a critical part to play in the field of education, particularly in the formal field of school, and teachers greatly influence the success of students, particularly in terms of the teaching - learning activities that is typically taken out within schools. The achievement of the teacher's performance is affected by the local environment. Consequently, the environment underlying the school, particularly in this situation, including the headmaster who is able to encourage and encourage educators to perform well and to be able to act as professional teachers in addition to the teachers themselves who are able to assess the efficiency with their own job. Kartini et al note that there is a major influence on the success of teachers between principal leadership, academic supervision and professional competence at the same time [1].

Teacher performance can be influenced by a number of factors, including the Principal's style of leadership and working condition. Professional teachers are believed to be able to make students think, behave and act creatively [2]. According to Invancevich [3], that performance is determined by biographical, psychological and organizational variables. Biographical variables include mental abilities and skills, family background, social level, experience, age and gender. Psychological variables include perceptions, attitudes, personality, learning and motivation. While organizational variables include leadership resources, status, structure, compensation and job design.

Effective leadership is a leadership style that can produce output through managing the performance of others. Leaders must ensure that subordinates do their work based on the skills and commitments they have according to their main tasks and functions to produce the best output [4]. Leadership style greatly affects work productivity. As a leader, the Principal becomes a promoter of the school community, in particular teachers, whose direction is aimed at achieving the vision, mission and objectives of the school [5]. The 
style of leadership embraced by the Principal would contribute to the results and success of the Principal in guiding and executing the school education process [6].

Principal leadership is an important factor that can encourage teacher performance in realizing the vision, mission, goals and targets to be achieved by the school. The position of the principal as a leader with a style of leadership must be able to influence other people or employees [7]. According to Leffton and Buota [8] in School Based Management (MBS), the principal is "the key person" for the success of improving education in schools. He is a person who is given the responsibility to manage and empower the various potentials of society and parents to realize the vision, mission and goals of the school. The Principal should be able to carry out inventions and be able to direct all stakeholders and the school as an educational institution [9].

Based on observations in schools, it shows that many school principals have not been able to influence the performance of teachers and staff towards progress, so that the potential that exists in human resources has not been optimally realized. The leadership functions according to Mulyasa [10] as a determinant of direction, spokesperson, communicator, midiator, integrator and management principles, namely division of labor, delegation of tasks and authority, government unity, group solidarity, initiative, have not been implemented properly

In addition to the problems mentioned above, the work environment is also an important problem in SMA in Muaradua District. The work environment concerns the availability of educational support or infrastructure, which is still inadequate or far behind compared to schools in cities. Meanwhile, other factors are related to the atmosphere of the school climate in relation to the less conducive work between teachers and employees.

The school work environment has an influence on the performance of a teacher in an effort to complete the tasks assigned to him which ultimately affects his success and achievement, a great environment will increase work, and vice versa, unless the workplace is less calm, the level of work errors they make will increase. A school is certainly inseparable from the environment, and is also involved with the environment around the school. Another definition of the work environment is that all physical factors together constitute an atmosphere that includes the workplace [11].

Based on that which encourages researchers to carry out further research on "The Effect of Principal Leadership Style and Work Environment on the Performance of High School Teachers in Muaradua District, Oku Selatan Regency".

\section{METHODS}

Research on the effects of the Headmaster's style of leadership and work environment upon its quality of primary school teachers in Muaradua, OKU Selatan, is a quantitative approach, using an observational method that uses observations and questionnaires. The research comprised of 3 represented in the form of two variables in this study variable. The factors identified were the headmaster's style of leadership $\left(\mathrm{X}_{1}\right)$ and the working condition $\left(\mathrm{X}_{2}\right)$ of the Principal and the dependent variables in this study was the performance of high school teachers in Muaradua OKU Selatan $\left(\mathrm{Y}_{1}\right)$.

\section{RESULTS AND DISCUSSION}

Effective contribution (SE) is a measure of the contribution of a predictor variable (independent) to the criterion variable (dependent) in the regression analysis. While the relative contribution (SR) is a measure that shows the size of the contribution of a predictor variable to the number of squares of the regression. Based on the data obtained from the regression analysis, the relative contribution and effective contribution of each predictor $\left(\mathrm{X}_{1}\right.$ and $\left.\mathrm{X}_{2}\right)$ percent $\mathrm{SR} \%$ are as follows:

a. Effective Contribution

Prediktor $\mathrm{X}_{1}$ : SE $\%=0,425 \times 0,638 \times 100 \%=$ $27,1 \%$

Prediktor $\mathrm{X}_{2}$ : SE $\%=0,356 \times 0,611 \times 100 \%=$ $21,75 \%$

\section{b. Relative Contribution}

Prediktor $\mathrm{X}_{1}: \mathrm{SR} \%=27,1 \% / 48,9 \%=55,4 \%$

Prediktor $\mathrm{X}_{2}: \mathrm{SR} \%=21,75 \% / 48,9 \%=44,48 \%$

From the results out of the above calculations, the effective contribution of the headmaster's style of leadership and work environment to teacher performance was $27.1 \%$ and $21.75 \%$.

The relative contribution of the headmaster's style of leadership and work environment to teacher performance was $55.4 \%$ and $44.48 \%$. This shows that any change in the headmaster's style of leadership and work environment determines changes in teacher performance.

The headmaster's style of leadership and work environment together have an effect of $48.9 \%$ on teacher performance, although the ones left $51.1 \%$ are affected by certain factors outside the study.

\section{CONCLUSION}

The results have shown that impact of the headmaster's style of leadership and work environment variables on teacher quality has been demonstrated $48.9 \%$ and the remaining $51.1 \%$ needed to be followed 
up with other studies through a qualitative approach to find out and reveal more clearly and deeply in an effort to improve performance. teachers or research with a quantitative approach with different independent variables such as organizational climate, facilities, expertise or skills, because these variables are thought to be correlated with teacher performance. The principal as the leader needs to improve his ability to apply the right type or style according to the situation and conditions by paying attention to the level of maturity, ability and willingness of the teacher so that the leadership style applied is truly effective in optimizing teacher quality as an achieving the expected educational objectives together. In addition, the principal is in order to condition and build a conducive working atmosphere and environment.

\section{REFERENCES}

[1] Kartini, D., Kristiawan, M., \& Fitria, H. (2020). The Influence of Principal's Leadership, Academic Supervision, and Professional Competence toward Teachers' Performance. Education and Training for Strengthening Principal to Effective Schools. International Journal of Progressive Sciences and Technologies (IJPSAT), 20(1).

[2] Ruslan, Lian, B., \& Fitria, H. (2020). The Influence of Principal's Situational Leadership and Teacher's Professionalism on Teacher's Performance. International Journal of Progressive Sciences and Technologies (IJPSAT), 20(1). Retrieved from https://ijpsat.ijsht-

journals.org/index.php/ijpsat/article/view/1733

[3] Invancevich, G., \& Dannelly. (1985). Organization 5th Edition (Organisasi Jilid 1 terjemahan Djarkasih. Jakarta: Erlangga.

[4] Gie,T. L. (2009). Administrasi Perkantoran Modern [Modern Office Administration]. Yogyakarta: Liberty.

[5] Suratman, S., Arafat, Y., \& Eddy, S. (2020). The Influence of Principal's Leadership and Teacher's Competence toward Teacher's Performance in Indonesia. Journal of Social Work and Science Education, 1(2), 96-104. Retrieved from https://ejournal.karinosseff.org/index.php/jswse/arti cle/view/32

[6] Astuti, R. W., Fitria, H., \& Rohana, R. (2020). The Influence of Leadership Styles and Work Motivation on Teacher's Performance. Journal of Social Work and Science Education, 1(2), 105-114. Retrieved from https://ejournal.karinosseff.org/index.php/jswse/arti cle/view/33

[7] Asvio, N., Yamin, M., \& Risnita. (2019). Influence of Leadership Style, Emotional Intelligence and Job Satisfaction toward Organizational
Commitment (Survey at SMA Muhammadiyah South Sumatera). International Journal of Scientific \& Technology Research 8 (8).

[8] Leffton \& Buota. (2005). Leadership Through People Skills. Jakarta: PT. Buana Ilmu Populer.

[9] Andriani, S., Kesumawati, N., \& Kristiawan, M. (2018). The Influence of the Transformational Leadership and Work Motivation on Teachers Performance. International Journal of Scientific \& Technology Research, 7(7).

[10] Mulyasa, E. (2003). Menjadi Kepala Sekolah Profesional [Become a Professional School Principal]. Bandung: Remaja Rosdakarya.

[11] Siagian, S. P. (2003). Teori dan Praktek Kepemimpinan [Leadership Theory and Practice]. Jakarta: Rineka Cipta. 